\title{
The Great Battle of the Books between the Cultural Evolutionists and the Cultural Relativists: From the Beginning of Infinity to the End of History
}

\author{
Kevin Jon Fernlund \\ Professor of History, University of Missouri, St. Louis \\ Correspondence I Kevin Jon Fernlund, fernlund@umsl.edu \\ Citation I Fernlund, Kevin Jon. 2020. "The Great Battle of the Books between the Cultural Evolutionists and the Cultural Relativists: \\ from the Beginning of Infinity to the End of History." Journal of Big History 4 (3): 6-30. \\ DOI I https://doi.org/10.22339.jbh.v4i3.4310
}

\begin{tabular}{l} 
K E Y W O R D S \\
\hline Civilization \\
Boaz \\
Marx \\
Anthropology \\
Relativism \\
Evolution \\
Lamark
\end{tabular}

\begin{abstract}
A B S T R A C T
The idea that societies or cultures can evolve and, therefore, can be compared and graded has been central to modern history, in general, and to big history, in particular, which seeks to unite natural and human history; biology and culture. However, while extremely useful, this notion is not without significant moral and ethical challenges, which has been noted by scholars. This article is a short intellectual history of the idea of cultural evolution and its critics, the cultural relativists, from the Age of the Enlightenment, what David Deutsch called the "beginning of infinity," to the neo-Hegelianism of Francis Fukuyama. The emphasis here is on Europe and the Americas and the argument is that the universal evolutionism of the Enlightenment ultimately prevailed over historical particularism, as global disparities in social development, which were once profound, narrowed or even disappeared altogether.
\end{abstract}

I must study Politicks and War that my sons may have liberty to study Painting and Poetry Mathematicks and Philosophy. My sons ought to study Mathematicks and Philosophy, Geography, natural History, Naval Architecture, navigation, Commerce and Agriculture, in order to give their Children a right to study Painting, Poetry, Musick, Architecture, Statuary, Tapestry and Porcelaine. ${ }^{1}$ John Adams to Abigail Adams, 1780

The idea that societies or cultures can evolve and therefore can be compared and graded has been central to modern history, in general, and to big history, in particular, which seeks to unite natural and human history: biology and culture. However, while extremely useful, this notion is not without significant moral and ethical challenges, which has been noted by scholars. This article is a short intellectual history of the idea of cultural evolution, and its critics, the cultural relativists, from the Age of the Enlightenment, what David Deutsch called the "beginning of infinity," to the neo-Hegelianism of Francis Fukuyama. The emphasis here is on Europe and the Ameri- cas and the argument is that the universal evolutionism of the Enlightenment ultimately prevailed over historical particularism, as global disparities in social development, which were once profound, narrowed or even disappeared altogether.

\section{Cultural versus Organic Evolution}

The French naturalist Jean-Baptiste Lamarck (1744-1829) was wrong about biology. Organisms do not pass on characteristics acquired in their own lifetimes to their offspring. A giraffe, for example, that learns to stretch its neck to reach leaves higher up a tree, cannot then pass on a 
longer neck to the next generation. Biological evolution or nature does not work that way. But Lamarck was right about human history. Humans individually or collectively learn new things all the time, and they may pass on this newly acquired knowledge to the next generation through formal or informal means. This is precisely how cultural evolution, or what one might call Lamarckian evolution, works. The idea was discovered and given full expression by the Enlightenment. $^{2}$

The modern idea that cultures have evolved and that they have the capability to progress, however, did not originate with the advent of critical history during the Enlightenment, marked by the eighteenth-century histories of David Hume, William Robertson, and Edward Gibbon. ${ }^{3}$ Rather, the idea formed earlier in the sixteenth and seventeenth-centuries, when English philosopher Francis Bacon looked back to Antiquity and opined that modern inventions have set the modern world apart from the ancient world. Bacon observes:

We should notice the force, effect, and consequences of inventions, which are nowhere more conspicuous than in those three which were unknown to the ancients; namely, printing, gunpowder, and the compass. For these three have changed the appearance and state of the whole world: first in literature, then in warfare, and lastly in navigation; and innumerable changes have been thence derived, so that no empire, sect, or star, appears to have exercised a greater power and influence on human affairs than these mechanical discoveries. ${ }^{4}$

Bacon was making the case for the Moderns in the Ancients versus the Moderns debate, which grew out of the Renaissance, with the rediscovery of classical learning, and intensified during the Scientific Revolution. Modern Europeans, Bacon argued, could see farther and better than their ancestors because they had powerful new optical instruments, such as the telescope and the microscope. Crucially, because of the scientific method (the testing of hypotheses), the Moderns had the tools and means to think better than the An- cients.

Not to be outdone by the scientists, scholars also developed the humanistic method to think better, which perhaps no one expressed better than did the Victorian educator Matthew Arnold. In an essay entitled "Culture and Anarchy" (1869), he wrote that culture ought to be the

pursuit of our total perfection by means of getting to know, on all the matters which most concern us, the best which has been thought and said in the world; and through this knowledge, turning a stream of fresh and free thought upon our stock notions and habits. ${ }^{5}$

Implicit in Bacon's argument for the superiority of the present over the past is the notion of progress, that knowledge could be increased, and that society, therefore, could be improved upon over what it had been before.

\section{Dynamic versus Static Societies}

The New World of Bacon was not just geographical; it was also psychological-a new state of mind. In short, as reflected in the methods of Bacon and René Descartes-and later with the work and achievements of Isaac Newton and John Locke-Western society had become "dynamic," to use the term of David Deutsch, a British physicist and philosopher of science. To Deutsch, a "static society involves," in contrast to a dynamic one, a "relentless struggle to prevent knowledge from growing." This conservatism was not irrational since, without science, there was no way to test whether a new idea was true or useful. Thus, in static societies, authorities sensibly viewed all ideas or innovations with caution, if not outright suspicion. Cultures that reproduce themselves by avoiding innovation and adhering to traditionwhere sons and daughters learn to copy their fathers' and mothers' ways of doing things-may have been static but they were also stable, which was a crucial achievement in what was otherwise a dangerous and an unpredictable world.

Dynamic, as opposed to static, societies, on the other hand, were exceedingly rare. To quote Deutsch again, modern Western civilization is "the only known instance of a long-lived dynamic (rapidly changing) society." Unlike those in static or traditional societies, participants in Western 
civilization were aware, sometimes keenly so, that change had occurred or was occurring during their own lifetimes, and they believed that change would go on to remake their children's world as well. In 1776 and 1789 Americans as well as the French, respectively, both embraced revolutionary change. As these two revolutions demonstrated, change was not a random occurrence but could be intentional and directed. Change also brought unintended consequences.

With the rise of freer markets, freer and regular elections, amendable constitutions, scholarly criticism, peer review, due process, freedom of the press, patents, double-entry bookkeeping, and many other processes and mechanisms of self -correction and transparency, including the very study of history itself, change became selfperpetuating and its pursuit institutionalized within new, fiercely competitive and increasingly powerful nation-states as well as within other forms of intrastate organizations, such as the joint stock company and later the business corporation. Even the simplest associations came to keep minutes and to divide the business into old and new.

These new freedoms certainly did not emerge all at once or occur everywhere. The development of a liberal or free culture, after all, was complex and multifarious, but the liberal ideal was grasped early, and by the end of the eighteenth century, progress toward its full realization had been made on a number of fronts-from Paris to Philadelphia. At the same time, the belief took hold that the future would or should be better than the past; that the next generation could expect to live better than the last. ${ }^{8}$

Thus, the great significance of the Scientific Revolution had far less to do with the science that the Bacons, Newtons, and Lockes produced during the seventeenth century than it did with the new and improved way of thinking that marked this change in intellectual history and which made possible the Enlightenment that followed in the next century. Reason, to say nothing of faith, was no longer enough. To quote Deutsch again, Europe's thinkers began to seek "good," that is, "testable" explanations. On the significance of this important break with the past,
Deutsch declared:

the sea change in the values and patterns of the whole community of thinkers, which brought about a sustained and accelerating creation of knowledge, happened only once in history, with the Enlightenment and its scientific revolution. An entire political, moral, economic and intellectual culture-roughly what is now called the 'West'-grew around the values entailed by the quest for good explanations, such as tolerance of dissent, openness to change, distrust of dogmatism and authority, and the aspiration to progress by individuals and for the culture as a whole. And the progress made by that multifaceted culture, in turn, promoted those values. ${ }^{9}$

In short, the West-Western Europe and by extension North America, i.e., the North Atlantic world-hit upon a variety of methods to test and, crucially, to self-correct for error. These methods would eventually, if selectively, be adopted by other parts of the world.

\section{Europe and America}

Modern Europeans not only began to compare themselves with, and distance themselves from, their Ancient but civilized ancestors from Greece and Rome, but they also began to compare their cultures (or their common European civilization) with, and distance it from, the Native cultures of the New World-peoples and lands unknown to the cosmographer Claudius Ptolemy and the other Ancients. To Europeans, the American aborigines seemed primitive because they lived closer to nature, if not actually, they thought, in a state of nature. This idea served as the philosophical jumping off point for the seventeenth-century social contract theorists like Thomas Hobbes, Bacon's contemporary, and John Locke. By the eighteenth century, an entire line of thought had emerged from the evolutionary notion that as primitive America now is, civilized Europe once was. Going to America, or the Pacific Islands, meant one traveled horizontally through space and went vertically backward through time. Thus, with the Renaissance, Europeans discovered the Ancients, their learned forebears, in their newly 
stocked libraries of translated texts; in the Age of Discovery, and well after, they encountered in real time and throughout the Americas representatives of what they took as their more primitive or savage progenitors. America was regarded, in short, as Europe's distant mirror.

\section{The West's Clenched Fist and Invisible Hand}

The Ancients versus Moderns debate, sometimes framed as the fight between authority and progress, or what Jonathan Swift satirized in 1697 as the "battle of the books," exhausted itself by the end of the seventeenth century. ${ }^{10}$ The idea of progress, however, not only survived into the next century, it expanded and thrived, and, later, in the writings of the Scottish Enlightenment philosophers, became richly adorned in theory but firmly based in common sense and in Scotland's own sense of recent history-the divide between Highlands and the clannish old ways, on the one hand, and Lowlands and the newer law-based, market-driven society, on the other. The theory of progress replaced the old declension narrative of sacred history, which traced the fall of man from Adam and Eve, to Noah and Moses, then to Christ, the Redeemer, and, finally, to the expectation and eschatology of the Second Coming and

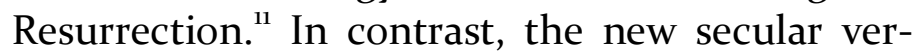
sion of history, as traced by the Scottish thinker Adam Ferguson in 1767 in his "An Essay on the History of Civil Society," was one of ascension, as "rude" states evolved into "polished" ones. Mankind was pointed toward ever greater refinement rather than salvation. ${ }^{12}$

In the Enlightenment's shift from a Godcentered to a human-centered history-and from a Jerusalem-centered map to a Eurocentric world geography-man arose out of nature rather than in the Garden of Eden. Humans then started their long career hunting and gathering. Hobbes had imagined that this primitive and savage state of affairs was a time when

every man is Enemy to every man; the same is consequent to the time, wherein men live without other security, than what their own strength, and their own invention shall furnish them withall. In such condition, there is no place for Industry; because the fruit thereof is uncertain; and consequently no Culture of the Earth; no Navigation, nor use of the commodities that may be imported by Sea; no commodious Building; no Instruments of moving, and removing such things as require much force; no Knowledge of the face of the Earth; no account of Time; no Arts; no Letters; no Society; and which is worst of all, continuall feare, and danger of violent death; And the life of man, solitary, poore, nasty, brutish, and short. ${ }^{13}$

Eventually, however, animals were domesticated, easing the struggle for existence. In this Pastoral or Arcadian stage, barbarians-a social grade higher than savages-came into being. They also invented and cultivated the simpler arts. As more time passed, plants were domesticated, giving rise to a higher level of culture-to an agriculture. In this stage, civilization replaced barbarism and the rude arts became ever more polished and refined. One of the key mechanisms, if not the most important mechanism, that propelled humanity forward, from a life that was "solitary, poore, nasty, brutish, and short," was war. For war made the state, Hobbes's "Leviathan," and the state, in turn, made peace. ${ }^{14}$ Ferguson agreed, adding

The strength of nations consists in the wealth, the numbers, and the character, of their people. The history of their progress from a state of rudeness, [was], for the most part, a detail of the struggles they have maintained, and of the arts they have practiced, to strengthen, or to secure themselves. Their conquests, their population, and their commerce, their civil and military arrangements, their skill in the construction of weapons, and in the methods of attack and defence; the very distribution of tasks, whether in private business or in public affairs, either tend to bestow, or promise to employ with advantage, the constituents of a national force, and the resources of war. ${ }^{15}$

Since this was the eighteenth century, when the Industrial Revolution (what the British mathematician and historian Jacob Bronowski called the "English Revolution" because it originated in England) was still inchoate, the highest stage of development seemed to contemporary observers 
to be a society based on commerce, trade, and some manufacturing, including incredibly productive pin factories. ${ }^{16}$ Indeed, Adam Smith, one of Ferguson's contemporaries and fellow countrymen, boldly argued in 1776 that these market activities alone, if allowed to proceed unhindered by undue government regulation, would eventually make the whole world rich. Thus, between Ferguson's clenched fist of the battlefield and Smith's "invisible hand" of the marketplace, the Enlightenment had not only described mankind's ascent but was prescribing new ways for mankind to ascend. In other words, they discovered by means of wars and markets that humans could break the "cake of custom," as the Victorians would later call it, and take charge of their own future. ${ }^{17}$

\section{The Rise and Fall of Empires}

The Enlightenment worked out schemes for how societies evolved or, as the case may be, devolved. Edward Gibbon famously advanced (the first of his six-volume history of Rome appeared in 1776) a two-part explanation for the decline and fall of the Roman Empire. The Latin West succumbed, he contended, to the spread from within of an increasingly intolerant monotheism, namely Christianity, and it failed, in the end, to repulse the barbarian invasions of the Goths, Vandals, and Huns. The Greco East, on the other hand, was assailed from without by barbarian Arabs and later, from without by the barbarian Turks who had converted to another monotheism, Islam. Thus, both halves of the Roman Empire were destroyed by barbarism and monotheism. Barbarians were, by definition, less civilized than the Romans. monotheists were, by definition, intolerant of other faiths. In this respect, differences in culture and cultural or social development were crucial to Gibbon's narrative.

These differences were in no way baked into anyone's DNA or racially determined. Enlightenment evolutionism was universal and selfevident-it applied to all peoples, in the past and in the present. Indeed, Gibbon pointed out that the very barbarian territories that had been carved out of the Roman Empire would one day evolve into the civilized states of Europe, such as
Gibbon's own England. In time, these new states not only caught up with Rome but improved upon and eventually surpassed Roman civilization in terms of social development. As Gibbon saw it, the period of the "Renaissance," a term coined by the nineteenth-century historian Jules Michelet, marked the rebirth of Rome, which had been destroyed centuries before by barbarism and superstition. With the Scientific Revolution and the transatlantic Enlightenment-Benjamin Franklin was as much a product of this era as was Voltaire-these Moderns were convinced that they would soar past the Ancients. The situation across the Atlantic was different. In the New World, members of Europe's transplanted civilization believed they were surrounded on every side by "savages" or "barbarians." Later, nineteenth-century historians, e.g., Francis Parkman and William H. Prescott, who continued to look at history through a Gibbonian lens, saw the rise of an independent Latin South and Anglo North as triumphs of Western civilization over American savagery and barbarism. ${ }^{18} \mathrm{~A}$ fear that these victories would be reversed haunted the Romantic imagination of the nineteenth century. ${ }^{19}$

\section{The End of American History-and Beyond}

There were many agricultural revolutions, but there was only one Industrial Revolution. The latter-day revolution started in the English Midlands and spread from there to the rest of the world. One of the intellectual consequences of this transformation was that the evolutionism or stage-theory of culture of the Enlightenment was all but eclipsed by the evolutionism of the nineteenth-century, which gave rise to two important variations on the older theme: Marxism, which explained social development in terms of class struggle, and Social Darwinism, which emphasized the survival of the fittest within different races as well as between them. Other writers, especially from the Americas, were drawn less to how cultures evolved or progressed and more to the conflicts that were produced when two cultures at different stages of development come into conflict, such as occurred when the peoples of Europe collided with the peoples of the Americas.

One of the most influential books in Latin 
American literature and history was Domingo Faustino Sarmiento's Civilization and Barbarism: The Life of Juan Facundo Quiroga, and the Physical Aspect, Customs, and Practices of the Argentine Republic, which was published in 1845 . The 184 os was a decade when the future of Sarmiento's Argentina, and much of the rest of Latin America, including Mexico, appeared very much in doubt. According to Sarmiento, Latin America was locked in a "struggle" between the opposing forces of European civilization, that is, "intelligence," which was focused in the port city of Bueno Aires, and "indigenous barbarism," which he equated with "matter" and the wild Pampas. Sarmiento believed that in the Argentine Republic the "nineteenth and the twelfth centuries live[d] together: one inside the cities, the other in the country." For Sarmiento, the New World was where European civilization was engaged in an ongoing clash with American barbarism, represented by its caudillos, military strongmen, and dictators, from Argentina's Juan Manuel de Rosas to Mexico's Antonio López de Santa Anna-the villain, from the Texas perspective, of the Battle of the Alamo in $1836 .^{20}$

In 1893, not quite fifty years after the appearance of Sarmiento's Civilization and Barbarism, and a little over four hundred years after Christopher Columbus discovered San Salvador, an island in the Bahamas, thereby changing the course of world history, Frederick Jackson Turner delivered a paper, "The Significance of the Frontier in American History." He did so at the meeting of the American Historical Association (AHA), which met in Chicago, where the World's Columbian Exposition was being held to celebrate Columbus's four hundred-year-old achievement. Turner's paper would prove as influential in Anglophone America as Sarmiento's book did in Latin America. In fact, Turner invented American history. ${ }^{21}$

Like Sarmiento, Turner saw American history as a struggle between indigenous barbarism, or what he called savagery, on the one hand, and civilization, on the other. The dividing line between these two stages of cultural or social development was the American frontier, a line that moved west from the founding of Virginia in 1607 to 1890 , when the nation had supposedly exhausted its free land and subjected its indigenous peoples who were then slated, like it or not, to be assimilated, i.e., turned into God-fearing, propertyloving farmers, even as America's farmers of European and African descent were leaving their farms in droves to work and live in the country's booming cities. For Turner, the struggle between civilization and savagery was central to American history because settling the frontier turned Europeans into Americans and it produced a new, rapidly evolving, democratic civilization, one thoroughly independent-politically as well as culturally-he believed, of Europe's. This was the significance of the frontier. However, now that the frontier was closed, as was declared by Robert P. Porter, the Superintendent of the 1890 Census, a chapter of American history was at an end. Turner expected subsequent American development to follow in Europe's footsteps. ${ }^{22}$

Andrew Jackson, after whom Turner's father gave Turner his middle name, bore a strong resemblance to Sarmiento's caudillos, especially his contemporary Juan Manuel de Rosas. Both men were noted Indian fighters and both cleared lands for European settlement. Whereas Rosas established a dictatorship in Argentina, Jackson turned the American Republic into a popular democracy with the spread of universal manhood suffrage. ${ }^{23}$ Sarmiento expressed his ideas in Facundo to protest Rosas's tyranny, while Turner wrote "The Significance of the Frontier" to analyze and celebrate the sources of American liberty and individualism. While Sarmiento called for the influence of more European culture on the manners of his country, Turner celebrated the distinctiveness of America's way of doing things. These two men offered powerful explanations-in prose bordering on poetry-for the history and culture of their respective countries, and, more generally, for Latin America and Anglophone America-the former typified by gauchos, the latter by the not-sodifferent cowboys. In return, Sarmiento and Turner were each offered power themselves. Sarmiento would go on to serve as the president of Argentina and Turner, who had befriended Woodrow Wilson as a graduate student at Johns Hopkins University in Baltimore, Maryland, 
would later serve as one of President Wilson's postwar planners. ${ }^{24}$

\section{Darwin and Marx}

At the end of the nineteenth century, the president of the American Historical Association, James Ford Rhodes, observed that the publication of Darwin's On the Origin of Species in 1859 had marked the dividing line between two intellectual worlds.

Evolution, heredity, environment, have become household words, and their application to history has influenced everyone who has had to trace the development of a people, the growth of an institution, or the establishment of a cause. Other scientific theories and methods have affected physical science as potently, but no one has entered so vitally into the study of man. ${ }^{25}$

To be more accurate, Darwin put biology into evolution (a word he initially did not use), although Jean-Baptiste Lamarck and others, including Darwin's own grandfather, Erasmus Darwin, had tried to do just that but not convincingly. The theory of natural selection, the discovery of which Charles Darwin shared with Alfred Wallace, made organic evolution finally acceptable to science. Darwin and Wallace were both inspired by Thomas R. Malthus's Essay on Population as It Affects the Future Improvement of Society (1798). Malthus postulated that human populations would, in time, always outstrip their environment, forcing the survivors into a grim competition for resources. Malthus's fatalism stood in sharp contrast to the optimism of Robertson and other Enlightenment thinkers.

In the wake of Darwin, the non-organic theory of evolution of the Enlightenment had all but been forgotten. Obviously, there was a great deal of continuity between eighteenth-century and nineteenth-century non-organic evolutionism, as indicated by the evolutionary stages of Ferguson on the one hand and Sarmiento and Turner on the other. The anthropology of Sir Edward B. Tylor and the New York railroad lawyer Lewis Henry Morgan were other cases in point.

In Primitive Culture, published in 1871, two years after the publication of Mathew Arnold's essay, Culture and Anarchy, Tylor produced the classic, non-organic, definition of culture. It was that "complex whole which includes knowledge, beliefs, arts, morals, law, customs, and any other capabilities and habits acquired by a man as member of society." ${ }^{26}$ In 1877 in Ancient Society, Morgan, who had conducted extensive field work among the Iroquois (as he was adopted by the Seneca), fleshed out the now very familiar, nonorganic, tripartite scheme of cultural evolution: 1) savagery; 2) barbarism; and 3) civilization. While for Adam Ferguson the drive for security was one of main drivers of cultural evolution, for Morgan it was the development of better food production technologies. As Morgan put it, "The great epochs of human progress have been identified, more or less directly, with the enlargement of the sources of subsistence."27

Morgan's thinking was, however, somewhat ambivalent on this point, probably because he was not an armchair theorist but had extensive experience in the field, meeting in person, for example, with members of the Iroquois nation. On the one hand, Morgan believed that a "common principle of intelligence meets us in the savage, in the barbarian, and in civilized man." This was quite literally an enlightened point of view. Ferguson similarly observed in 1767 that "[w]e are generally at a loss to conceive how mankind can subsist under custom and manners extremely different from our own; and we are apt to exaggerate the misery of barbarous times, by an imagination of what we ourselves should suffer in a situation to which we are not accustomed. But every age hath its consolations, as well as its sufferings. In the interval of occasional outrages, the friendly intercourses of men, even in their rudest condition, is affectionate and friendly." In other words, ages and stages may come and go but there is a durability to mankind's intelligence and humanity. ${ }^{28}$

On the other hand, Morgan acknowledged what would have seemed obvious to his European and European American contemporaries, which was that the "Aryan family" had become "the central stream of human progress, because it produced the highest type of mankind, and because 
it has proved its intrinsic superiority by gradually assuming the control of the earth." Here we see the unfortunate blurring of the Aryan family of race with evolution's highest type and with it, notions of racial superiority: that all men are not created equal, after all. This view marked an abandonment of one of the Enlightenment's most important self-evident truths. In the second-half of the nineteenth century, we see the comingling of biology and culture; of the organic and the non -organic. Even so, the Aryan Morgan nevertheless believed that the actual timing of the West's attainment of modern civilization was largely a matter of luck; it "must be regarded as an accident of circumstances." ${ }^{29}$ This was more the language of a cultural evolutionist, one with an appreciation of the role of contingency in history, than a racial determinist.

The bearded duo Karl Marx and Friedrich Engels considered Morgan's cultural evolution to be essential to understanding their own parallel theory of developmental stages, namely, 1) slavery; 2) feudalism; and 3) capitalism. Indeed, according to Engels, "in America, Morgan had, in a manner, discovered anew the materialistic conception of history, originated by Marx forty years ago. ${ }^{10}$ Despite Morgan's emphasis on technology rather than race, the anthropologist Marvin Harris notes that a "generation of anthropologists" was "brought up to believe" that Morgan was a racial determinist, which discredited him and other nineteenth-century evolutionists, and, ignorant of Morgan's eighteenth-century antecedents, believed "that the division of cultural history into the universal stages of savagery, barbarism, and civilization" was Morgan's "ill-advised latenineteenth-century accomplishment." With Morgan, cultural evolution was conflated with organic evolution, actually with Social Darwinism, after Herbert Spencer..$^{31}$

The high point of nineteenth-century evolutionism came in 1896, with the completion of Herbert Spencer's multivolume work, The Synthetic Philosophy. Volume One, First Principles, the first of ten volumes, appeared in 1862, followed by Principles of Biology (two volumes), Principles of Psychology (two volumes), Principles of Sociology (three volumes), and Principles of
Ethics (two volumes). A school teacher and a railway civil engineer, Spencer sought to apply the principles of evolution, including Darwin's theory of natural selection, to biology and to culture alike. Spencer was not content to describe. He prescribed that governments restrain themselves in order to allow for maximum competition in the market place and elsewhere, for that was, he argued, the key to progress in every sphere of human activity. Spencer, it should be noted here, was influenced by Auguste Comte, the French philosopher and founder of sociology. Comte, who believed there was an order and logic to the development of knowledge, divided the course of human history into three clear stages of development: 1) the theological; 2) the metaphysical; and 3) the positive or scientific. (There are almost as many developmental schemes as there are evolutionists!) $)^{32}$

While Spencer adopted a laissez-faire philosophy in regard to government's role in the economy and in society, which was influential primarily in the English-speaking world, the followers of Comte, especially in Latin America, including Mexico, arrived at the opposite conclusion. In the second half of the nineteenth century, the positivists in Mexico-the cientificos, as they were called-urged the government of Porfirio Díaz to engage in social engineering in order to fastforward, leap-frog, or accelerate the country's evolution and thereby catchup with the more advanced societies in Western Europe and North America ${ }^{33}$ Later, Marxist-Leninists in Russia and China who also believed that what is past is prologue would likewise promise shortcuts to modernization by means of "five-year plans" and "great leaps forward." On the right, Corrado Gini, an Italian statistician who was interested in the demographic evolution of nations-he favored a cyclical theory of population over Thomas Malthus's theory of constant geometric increasedeveloped the "Gini coefficient," on the eve of the First World War. This index, which measured the dispersion of wealth in a society, could test the ideas of a Marx or of a Turner, to determine whether a society was advancing toward greater inequality or toward greater equality. It could also be used to evaluate the efficacy of national 
policies and programs-the importance of which cannot be overstated. In Gini's case, it was used to inform the fascist, racist, and expansionist policies of Benito Mussolini. ${ }^{34}$

\section{Boas and White}

The rejection of Social Darwinism, which started at the end of the nineteenth century, was complicated. In the new historical discipline (for which the American Historical Association was founded in 1884), Turner's frontier theory was free of the class reductionism of the Marxists and of the racial determinism of the Social Darwinists. In many respects, his history was a refreshing throw-back to eighteenth-century evolutionism, directionality, and progress. Indeed, it was an explicit and forceful rejection of the Anglo-Saxon and Eurocentric race-based germ theory that prevailed in American historiography during the 188 os and 1890 s. $^{35}$

Like Marx, Turner was interested in social change. Whereas, Marx emphasized class conflict within a society, Turner was more interested in the conflict between societies at different stages of development, namely in the violent collision that occurred between civilization and savagery on the American frontier. Also, whereas, Marx wrote of individuals in terms of their class interests, Turner was interested in individuals principally as representatives of different stages of social development. For instance, Turner's writing is peppered with references to individuals as hunters, herders, farmers, town-builders, and, later, of regional or sectional types. ${ }^{36}$ Turner was certainly guilty of harboring a narrow nationalism, and his ideas lost much of their relevance in the broader campaigns to save Western civilization during the world wars and ideological struggles of the twentieth century. ${ }^{37}$ His evolutionary, exceptionalist, and narrative ideas nevertheless had a lasting impact on American historiography.

The situation in anthropology was quite different. Turner's contemporary, Franz Boas, the "father of American anthropology," and his numerous students would reject organic evolution and call non-organic evolution into question as well. As early as 1894, Boas, a German-born immigrant, began to lay out his line of attack. He opposed the notion that the biological evolution of humans could have taken place in the recent prehistoric and historic eras. Evolution takes time, lots of it. Five thousand years, the time of recorded history, was simply not a sufficient amount of time, Boas thought, for the occurrence of any significant divergent physiological transformations. Boas did think, however, that cultures evolved over time but not necessarily in a sequential or linear order. Boas did not think that Western culture was necessarily superior to, or more advanced than, other cultures, a view that put him at odds with the racial determinists of the day. "Why, then," he asked, "did the white race alone develop a civilization which is sweeping the whole world, and compared to which all other civilizations appear as feeble beginnings cut short in early childhood, or arrested and petrified in an early stage of development?" Cultures, he said, existed in relation to, and were influenced by, each other. Their differences were the result of historical particularities, if not accident or the "laws of chance" (on the point of contingency as, interestingly, Boas was not that far apart from Morgan). History, in short, was an amoral game of thrones and Western culture was-for the moment-on top. ${ }^{38}$

Boas illustrated the point in this way: It would seem that the civilizations of ancient Peru and of Central America may well be compared with the ancient civilizations of the Old World. In both we find a high stage of political organization, division of labor and an elaborate ecclesiastical hierarchy. Great architectural works were undertaken, requiring the cooperation of many individuals. Plants were cultivated and animals domesticated; the art of writing had been invented. The inventions and knowledge of the peoples of the Old World seem to have been somewhat more numerous and extended than those of the races of the New World, but there can be no doubt that the general status of their civilization measured by their inventions and knowledge was nearly equally high. This will suffice for our consideration. What, then, is the difference between the civilization of the Old World and that of the New World? It is essentially a difference in time. The one reached a certain stage three thousand or four thousand years sooner than the other. 
Although much stress has been laid upon the greater rapidity of development of the races of the Old World, it is not by any means conclusive proof of exceptional ability. It may be adequately conceived as due to the laws of chance. ${ }^{39}$

Boas's cultural relativism or historical particularism, was a criticism of anthropological theory-of evolutionism - which was being used to justify, among other things, white supremacy in the American South and Anglo-Saxon Protestant dominance elsewhere in the country as well as to underpin Western imperialism throughout the world. ${ }^{40}$ In short, anthropology had been politicized as well as turned into public policy in the late nineteenth and early twentieth centuries by the Social Darwinists and, later, in the 1930s, the same science, Boas observed with growing alarm, was being "subjected" to racial prejudice in "countries controlled by dictators," in a clear reference to Adolph Hitler and Nazi Germany. In the preface to the revised edition of The Mind of Primitive Man, which was published in 1911 and reissued in 1938, Boas reasserted the point that there was "no fundamental difference in the ways of thinking of primitive and civilized man," again, knowingly or not, echoing Morgan; furthermore, there has "never been established" a "close connection between race and personality;" and finally, the very "concept of racial type as commonly used even in scientific literature is misleading and requires a logical as well as a biological redefinition." ${ }^{\prime 1}$

To fight against this popular and ignorant prejudice, Boas sought, in effect, to re-politicize the discipline, to divorce cultural from physical anthropology, which he accomplished with the help of his students. In Man's Most Dangerous Myth: The Fallacy of Race, which was written under Boas's direction and published in 1942 during the war against the Third Reich, Ashley Montagu stated categorically that there was "absolutely no genetic linkage for genes with physical traits, mental capacities, or civilization-building abilities." In 1943, the following year, Margaret Mead, another Boas student, who had written the classic study Coming of Age in Samoa (1928), fleshed out the Boasian creed in "The Role of Small South Sea Cultures in the Post War World," an article that appeared in the American Anthropologist. "As anthropologists," she wrote, "our contribution has been a recognition of the co-equal value of human cultures seen as wholes.... We have stood out against any grading of cultures in hierarchical systems which would place our own culture at the top and placed the other cultures of the world in a descending scale according to the extent that they differ from ours. Refusing to admit that one culture could be said to be better than another... [,] we have stood out for a sort of democracy of cultures, a concept which would naturally take its place beside the other great democratic beliefs in the equal potentiality of all races of men, and in the inherent dignity and right to opportunity of each human being." In 1946, in her study of Japan, Ruth Benedict, yet another Boas student, declared that the goal of anthropology was "to make the world safe for human differences." In 1952, the Boas student Alfred L. Kroeber and Clyde Kluckhohn (who was not a Boas student) further disentangled the concept of culture and its study from race by clearly and very usefully delineating culture as a "set of attributes and products of society, and therewith of mankind, which are extrasomatic and transmissible by mechanisms other than biological heredity." ${ }^{2}$

The program of the cultural relativists, or the anti-theory particularists, lined up perfectly, as Marvin Harris observed, with the "fundamental ideological outlook associated with left-of-center political liberalism." 43 The Boasians had successfully put the Social Darwinists and other racial determinists, to their right, on the defensive. In the process, and dare one say in theory, they threw the Marxists, to their left, out with the bath water. Marxists graded cultures and placed the West - with the rise of industrial capitalism in Europe, the United States, and Canada-at the top. ${ }^{44}$ Marxism may have been ethnocentric, but it was not necessarily racist. Indeed, for students of Das Kapital class struggle, not racial determinism, was what drove change. Thus, Marxists had to contend not only with the progressive antiracism and cultural relativism of the Boasians from within anthropology, but also, from 1945 on, with the advent of the Cold War, a growing atmosphere of anti-Communism and 
reactionary politics outside anthropology.

While Social Darwinism was being eclipsed by cultural relativism, at least in the United States, Darwinian natural selection was being complemented, indeed empirically confirmed, by Mendelian heredity. In 1942, Julian Huxley, the grandson of T. H. Huxley, who was known as Darwin's bulldog for his fierce advocacy of life's mutability and Darwin's theory for explaining that mutability, called this crucial modification to the theory of evolution the "modern synthesis" or fusion of natural selection (and its later revisions, e.g., group selection, genetic drift, and punctuated equilibrium or "punk eek") and the laws of inheritance. $^{45}$

Given the vindication of biological evolution by genetics, it was only a matter of time before there would be a revival of cultural evolution in some form, and with it the notion of directionality or progress. Writing in London during some of the darkest days of the Second World War, Julian Huxley-seemingly unfazed by the German blitz-observed calmly that "[a]fter the disillusionment of the early twentieth century it has become as fashionable to deny the existence of progress and to brand the idea of it as human illusion, as it was fashionable in the optimism of the nineteenth century to proclaim not only its existence but its inevitability. The truth is between the two extremes." ${ }^{16}$ However, when the revival came, one year later, cultural evolution's source of inspiration was not the modern synthesis of the life sciences but modern physics-for this was, after all, also the Heroic Age of Relativity and Quantum Mechanics. ${ }^{47}$

In 1943, the anthropologist Leslie White published "Energy and the Evolution of Culture." This remarkable article appeared in the pages of the American Anthropologist in the issue that immediately followed the one containing the Margaret Mead piece on planning Oceania's future. This was the article in which she articulated the Boasian creed of cultural relativism, thereby putting belief or political commitment ahead of science; there is a fine line between creed and dogma. White taught at the University of Michigan and was an unreconstructed nineteenth-century evolutionist who saw his work picking up right where his predecessors Lewis Henry Morgan, Herbert Spencer, Edward Tylor, and Karl Marx left off, sans the racial determinism. ${ }^{48}$ On this important point, White was emphatic: "Although peoples obviously differ from each other physically, we are not able to attribute differences in culture to differences in physique (or "mentality"). In our study of culture, therefore, we may regard the human race as of uniform quality, i.e., as a constant, and, hence, we may eliminate it from our study." White removed race from the table and focused instead on the purity of energy; by energy he meant the "capacity for performing work." White declared, "Everything in the universe may be described in terms of energy. Galaxies, stars, molecules, and atoms may be regarded as organizations of energy. Living organisms may be looked upon as engines that operate by means of energy derived directly or indirectly from the sun. The civilizations, or cultures of mankind, also, may be regarded as a form or organization of energy." In 1959, he would call civilizations or cultures "thermodynamic systems." 49

White eliminated race and he eliminated place from his study as well. Just as he considered the former a constant, he considered habitat, even though "no two habitats are alike," to be also a constant. He did so by reducing the "needserving, welfare-promoting resources of all particular habitats to an average." Having dispensed with the constants of race and place (but not class as he was a clandestine Socialist), White then turned to the three variables of energy, technology, and product. That is, 1) "the amount of energy per capita per unit of time harnessed and put to work within the culture;" 2) the "technological means with which this energy is expended," and 3) the "human need-serving product that accrues from the expenditure of energy." White expressed the relationship of these variables in a formula: $\mathbf{E} \mathbf{x} \mathbf{T}=\mathbf{P}$ (Energy expended per capita per unit of time) $\mathrm{x}$ (the Technological means of its expenditure $)=($ the magnitude of the Product per unit of time). To illustrate, he wrote that "[o]ther things being equal, the amount of wood" a workman cuts "varies with the quality of the axe: the better the axe the more wood cut." It follows, White argues, that a workman can "cut 
more wood with iron" than "with a stone axe." Iron Age cultures, to generalize, were able to capture and use more energy than Stone Age cultures. White had thus produced an energy index that he used to compare, evaluate, and grade the cultural evolution of different societies..$^{50}$

White was sharply critical of the cultural relativists for their full retreat from evolution. As he put it, "It seems almost incredible that anthropologists of the twentieth century could have repudiated such a simple, sound, and illuminating generalization, one that makes the vast range of tens of thousands of years of culture history intelligible, yet they have done just this. The antievolutionists, led in America by Franz Boas [and in Great Britain by Bronislaw Malinowski], have rejected the theory of evolution in cultural anthropology-and have given us instead a philosophy of 'planless hodge-podge-ism." To White, the fact-centered descriptions of the cultural relativists or "historical particularists" got thicker and thicker and, as they did so, they signified less and less. ${ }^{51}$ White also distinguished evolution from history. Evolution was the story of progress or of retrogression, while "history was the chronological sequence of particular events." He further added that the "historical process [was] particularizing; the evolutionary process [was] generalizing." He insisted that "by and large, in the history of human culture, progress and evolution have gone hand in hand..$^{2}$

In the years leading up to the centennial of Darwin's On the Origin of Species, cultural evolution reemerged as a viable theory, as the neoevolutionists, White foremost among them, swam hard against the Boasian tide. It was in 1959 that White's The Evolution of Culture: The Development of Civilization to the Fall of Rome was published. Grand generalization, it seemed, was back. ${ }^{53}$ Like the evolution of Marx, Spencer, Tylor, and Morgan, White's evolution was universal and he accepted, unapologetically, that the industrial and capitalist West, propelled by what he called the "Fuels Revolution," was the world's most advanced society. Looking back on the field in 1971, Elman R. Service, a White student, noted that despite the obvious utility of neoevolutionary ideas, "Leslie A. White, Julian A.
Steward, and [in Europe], V. Gordon Childe were virtually alone in opposing the antievolutionary temper of the times. It was not until after midcentury that there was any noticeable shift in opinion toward an evolutionary outlook again, and this took place only in America, only in anthropology, and there only in small part." ${ }^{\prime 54}$ This small part grew even smaller, with the unrest of the 1960s and early 1970s. In 2000, Marshall Sahlins, another one of White's students, reflected that "sympathy and even admiration for the Vietnamese struggle, coupled to moral and political disaffection with the American war, might undermine an anthropology of economic determinism and evolutionary development. ${ }^{\prime \prime 5}$ Indeed.

\section{The Two Cultures: Ruskin and Snow}

The same year (1959) that White published The Evolution of Culture, the English novelist and chemist Charles Percy Snow warned that Western civilization was splitting into two cultures-a culture of the math and sciences, on the one hand, and a culture of the arts and humanities, on the other. Snow believed that for the developed West to render effective aid to the underdeveloped world, it was crucial to repair the growing breach between these two cultures. The year 1959 was, after all, the height of the Cold War and he was very clear about which side he wanted to win-the West. Snow was critical of both cultures for their basic ignorance of each other, but his real target was, in his view, the backward-looking humanities; to the "intellectuals as natural Luddites." ${ }^{56}$

First, more background information and context-in the nineteenth century, the Victorian art critic John Ruskin had believed Western civilization went off the rails, although he would not have appreciated the metaphor, with the rebirth of classical learning and the influence of Greek and Roman models on European literature, art, and politics. This change was represented by replacement of organic and communal Gothic art of the Middle Ages in favor of the "rigid, cold, and inhuman" geometry of the Renaissance and emphasis on individual genius and ego rather than the anonymity and raw energy of the medieval workman. ${ }^{57}$ In The Stones of Venice (1851-1853), 
Ruskin charted the rise and fall of La Serenissima through its architecture, marking its height with the triumph of Gothic and, in the third of three volumes, its "fall," with the advent of the "Roman Renaissance." This latter movement was characterized by the "pride of science," the "pride of state," and the "pride of system" in which knowledge was arrogantly reduced or "caged" and manacled" to philosophy. In other words, an earlier Christian calmness was replaced by the discordant individualism of the Pagan world. To Ruskin, the Renaissance "preferred science to emotion, and experience to perception." Ruskin's cultural history is a perfect inversion of Enlightenment historiography-that the Renaissance, after a thousand-year hiatus of backwardness, fear, and superstition-more or less- restored high civilization to Europe. For Gibbon, as we have seen, the Renaissance marked the rebirth of Rome, while for Ruskin it was the cultural movement that murdered the Middle Ages. ${ }^{58}$

In reaction to what was, in Ruskin's view, Victorian England's money-grubbing and materialist culture, he championed the Pre-Raphaelite Brotherhood and inspired the Arts and Crafts movement. The Pre-Raphaelites tried to recapture in their representational paintings the magic and romance of an imagined Arthurian or Christian pastoral past. Ruskin's Romantic counterparts in America were the Transcendentalists Henry David Thoreau and Ralph Waldo Emerson and the artists Thomas Cole, Frederic Edwin Church, and Albert Bierstadt of the Hudson River and Rocky Mountain Schools. In North Ameri$\mathrm{ca}$-whether in the eastern woodlands and river valleys or later in the western mountains, plains, and deserts-artists learned early on to substitute the continent's natural landscapes and geology for Europe's legends and antiquity. Nevertheless, this transatlantic art had one thing in common: it was a form of redemption from either the weary, Ozymandias-cycle of the rise and demise of civilizations, which, after Gibbon's history of Rome, long haunted the Romantic imagination; or, it was an escape to nature from the Dickensian and dispiriting realities of the Industrial Age.

To counter the mind-numbing tasks, the division of labor, manager-worker alienation, the dan- gers of the factory floor, and the banality of massproduction, the designers, including William Morris, in the Arts and Crafts movement, many of whom were utopians and socialists, tried to revive the high craftsmanship and pride in the workplace they believed had once existed in the Middle Ages. ${ }^{59}$ These aesthetic visions were also shared throughout the British Empire and well into the twentieth century. In 1909, Mohandas K. Gandhi applied Ruskin's nostalgic critique to India in his anti-colonial and anti-modern tract Hind Sawraj or "Indian Home Rule." On machinery Gandhi wrote that it is "the chief symbol of modern civilization; it represents a great sin. . . [, and] it is machinery that has impoverished India." ${ }^{60}$ As for the effects of Westernization on India, he wrote:

Only the fringe of the ocean has been polluted and it is those who are within the fringe who alone need cleansing. We who come under this category can even cleanse ourselves because my remarks do not apply to the millions. In order to restore India to its pristine condition, we have to return to it. In our own civilization there will naturally be progress, retrogression, reforms, and reactions; but one effort is required, and that is to drive out Western civilization. All else will follow. ${ }^{61}$

Finally, Gandhi, believed that India's future was in its villages, not in its towns or cities.

Snow, however, would have none of what he considered to be elite handwringing, fantasy, or escape; in fact, he pointedly criticized Ruskin, William Morris, Thoreau, Emerson, and D. H. Lawrence for their "screams of horror" at the dehumanizing effects of industrialism and modernity. To Snow, however, the only sure way to improve the lives and health of the ordinary person was through applied science, technology, and industry. He lectured:

It is all very well for us, sitting pretty, to think that material standards of living don't matter all that much. It is all very well for one, as a personal choice, to reject industrialization-do a modern Walden, if you like, and if you go without much food, see most of your children die in infancy, despise the comforts of literacy, accept twenty years off your own life, then I 
respect you for the strength of your aesthetic revulsion. But I don't respect you in the slightest if, even passively, you try to impose the same choice on others who are not free to choose. In fact, we know what their choice would be. For, with singular unanimity, in any country where they have had the chance, the poor have walked off the land into the factories as fast as the factories could take them. ${ }^{62}$

Still, during the 196os the divide between Snow's two cultures widened even further-with an important difference. The cultural relativists of the prewar era, the Boasians, had been critical of any theory or system in which cultures or peoples were compared against or contrasted with Western culture or development. By these lights, evolutionists were ethnocentric. Margaret Mead had declared that anthropology's great "contribution" was the "recognition of the co-equal value of human cultures seen as wholes." However, the cultural relativists of the postwar, countercultural era-whose research and writing were deeply influenced by the various agendas of anti-colonial, civil rights, environmental, and other reform movements-began to replace Mead's neutrality on the co-equal value of cultures with far more radical, and increasingly, anti-Western positions. To these morally committed scholars and writers, other cultures were no longer co-equal with, but were, in fact, morally superior to, the West-a civilization that was more and more regarded as violently at odds with itself, with nature, and with the rest of the world. ${ }^{63}$

It was in this zeitgeist that the zoologist E. O. Wilson dared to resurrect the idea that biology and human culture have gradually co-evolved, producing ever greater complexity over time. $\mathrm{He}$ also asserted that some human behavior or traits may have a genetic basis. Wilson advanced these arguments in a book entitled, Sociobiology: The New Synthesis (1975), a title that recalls Julian Huxley's 1942 work. Wilson found himself immediately inside an interdisciplinary firestorm of controversy. He was called a fascist and a reductionist and accused by critics, notably fellow biologists and Marxists Stephen Jay Gould and Richard Lewontin, of offering a new defense of Social Darwinism, eugenics, and scientific racism.
Curiously, Wilson, who believed in directionality in human evolution, that is, in the idea of progress in history, attacked or demonized Lewontin and Gould for their Marxism. Channeling Boas and Mead and with Wilson in mind, Lewontin charged, "It is not surprising that the model of society" of biological determinists always "turns out to be natural, just and unchangeable" and it "bears a remarkable resemblance to the institutions of modern industrial Western society, since the ideologues who produce these models are themselves privileged members of just such societies." Lewontin really was a committed Marxist, while Gould was more attracted to Marx's dialectical theory of historical change on the one hand and to Kuhn's paradigm-shifting epistemology on the other. ${ }^{64}$ If all of this was not enough to ponder, Wilson conceded also that "Marxism is sociobiology without the biology," while Gould viewed evolution as a series of disruptions - a random and pointless process rather than one that was gradual and progressive. Yet, Gould allowed that cultures or societies could progress from one generation to the next because of Lamarckian selflearning, whereas biological mutability was the result of other mechanisms. In what was an instance of true intellectual diversity, all three scientists worked in the same building: Harvard's Museum of Comparative Zoology. ${ }^{65}$

\section{Rostow and Batalla}

Many in the developed world, beginning with the Missouri-born U. S. President Harry S. Truman, thought it was in the interest of the developed world, or capitalist world, or "First World," that is, the West (which would later include Japan-the modern West was socially vertical not geographically horizontal) to assist the underdeveloped world, or "Third World," to progress, evolve, modernize, or Westernize (modernists used these terms interchangeably). This was the enlightened thinking behind Truman's 1949 Point Four Program. For if the West failed to assist in the economic development of the "Third World," then that would likely result in these underdeveloped countries turning to the socialist states of the "Second World," principally, the Soviet Union and later the Peoples Republic of China, for help 
in modernizing their societies. In exchange for this assistance, Third World countries, it was feared, would align themselves with or allow themselves to be used by the Second World against the First World. The Cuban Missile Crisis, which occurred in October 1962, was the perfect realization of this triangle of worries over the asymmetry of global social development. ${ }^{66}$

To guide U. S. policy overseas, the American Walt Whitman Rostow developed a model of economic growth, which was published in 1960 under the title, The Stages of Economic Growth: A Non-Communist Manifesto. The subtitle was intended to differentiate his modernization theory from Marxist theory, which had become the ideology of the enemies of the "Free World" (one among many worlds in those days) - led by the United States-during the protracted Cold War. Rostow's five stages of development were these: 1) traditional society; 2) pre-conditions for take-off; 3) take-off; 4) drive to maturity; and 5) age of high mass consumption. Rostow went on to serve as the National Security Advisor to President Lyndon Johnson during the Vietnam War. ${ }^{67}$

Since the Second World War, the United States had helped to create a number of international as well as national programs and agencies to address the problem of human development. The United Nations, the International Monetary Fund, the World Bank, along with the Alliance for Progress and the Peace Corps were some of the most important state-supported examples. Rostow's modernization theory made explicit the philosophy underlying these different bodies. At the close of the Cold War, this national idea went global when in 1990-a year after the fall of the Berlin Wall-the United Nations adopted the Human Development Index (HDI), which had been devised by Mahbub ul Haq of Pakistan (who had been an advisor at the World Bank under Robert McNamara, the former U. S. Secretary of Defense for U. S. Presidents Kennedy and Johnson).

Haq explained his method for constructing the HDI: "Longevity is measured by life expectancy at birth as the sole unadjusted indicator. Knowledge is measured by two education variables: adult literacy and mean years of schooling, with a weight of two-thirds to literacy and one-third to mean years of schooling.... The third variable, income... is merely a proxy for a bundle of goods and services needed for the best use of human capabilities." Haq saw the HDI as a return to classical economics. Haq's three traits closely mirror Benjamin Franklin's "healthy, wealthy, and wise." The "founders of economic thought," he wrote, "never forgot that the real objective of development was to benefit people-creating wealth was a means. That is why, in classical economic literature, the preoccupation is with all of society, not just the economy. After the Second World War...an obsession grew with economic growth models and national income accounts. What was important was what could be measured and priced. People...were forgotten." From this perspective, Haq's HDI was a long overdue corrective. ${ }^{68}$

Thus, the index measured a country's economic development by focusing on the well-being of its people as opposed to the production of goods and services (Gross National Product or GNP) and was used to grade and evaluate every country in the world. Actually, Haq thought HDI should complement GNP because "GNP, by itself, reveals little about how the people in a society live and breathe." The beauty or crudity of the HDI was its sheer simplicity: each country was assigned a single composite number. Not surprisingly, the most economically advanced countries in the West or in the richer northern hemisphere scored much higher (Norway consistently topped the list) than did the less advanced countries in the Third World, primarily those in Sub-Saharan Africa, e.g., Sierra Leone, the South Sudan, and the Central African Republic. ${ }^{69}$ Margaret Mead would have rolled over in her grave.

In fact, the reaction of the postmodernists and the anti-globalists to "development-alism" (the idea of development had been reduced to an "ism" or an ideology) closely resembled the earlier critiques of cultural evolutionism by Mead and the cultural relativists. Except that the postmodernists were deeply suspicious of science and capitalism, two of modernism's greatest achievements. In the words of Carolyn Merchant, a radical ecologist (not ecologist who is radical but theorist of radical ecology), "Science is not a process of discovering the ultimate truths of nature, as 
the Enlightenment thinkers would have argued, but a social construction that changes over time. The assumptions accepted by its practitioners are value-laden and reflect their places in both history and society, as well as the research priorities and funding sources of those in power." ${ }^{\circ 0}$

Who was in power? According to the antiglobalists, it was the elites in the Group of 7 or $\mathrm{G}_{7}$ countries-France, Italy, Germany, Japan, the United States, the United Kingdom, and Canada. After having been involved in two world wars, these countries decided to abandon competition, which was costly and destructive, and embrace cooperation, which allowed them to govern the world for their own immense economic and political benefit. The differences, then, between more advanced and less advanced countries, between the rich and the poor countries, between the North and the South hemispheres (divided along the "Brandt Line," a global version of Turner's frontier of social development), were due not to cultural evolution but to global systems of inequality-imperial and neo-imperial systems that had been created by the West to extract wealth from, as well as to lord over, the Rest. ${ }^{71}$

These feelings and views were especially pronounced among intellectuals in Latin America, a region that had experienced the wrenching "lost decade" (La Década Perdida) of the 1980s. Barbara Weinstein, a specialist on Brazil who was president of the American Historical Association in 2007, pointed out that with this decade-in which the economies of Latin America, including that of Mexico, fell behind and deep into debtthe Enlightenment notion of progress came under the harshest scrutiny. According to Weinstein, the "crisis of the 1980s catalyzed a more radical, thoroughgoing, root-and-branch offensive against the very idea of development." Postmodernists or post-development thinkers, Weinstein notes, took the position that development was a discourse that needed to be deconstructed, choosing to ignore that development was actually a process, as the empiricist Haq had shown, which could be objectively measured. These critics also attacked "developmentalists of every stripe for representations of the so-called 'developing world' as landscapes of unrelieved poverty, misery, and backwardness, and for setting up Western standards as the universal benchmarks for economic, political, and cultural success." ${ }^{72}$

Perhaps the strongest rejection of Western development or the Eurocentric notion of progress came from the Mexican anthropologist Guillermo Bonfil Batalla. In 1987 in what amounted to a manifesto, which called to mind Gandhi's anticolonial views, thundered:

The recent history of Mexico, that of the last five hundred years, is the story of permanent confrontation between those attempting to direct the country toward the path of Western civilization and those, rooted in Mesoamerican ways of life, who resist. The first plan arrived with the European invaders but was not abandoned with independence. The new groups in power, first the creoles and later the mestizos, never renounced the westernization plan. They still have not renounced it. Their differences and the struggles that divide them express only disagreement over the best way of carrying out the same program. The adoption of that model has meant the creation within Mexican society of a minority country organized according to the norms, aspirations, and goals of Western civilization. They are not shared, or are shared from a different perspective, by the rest of the national population. To the sector that represents and gives impetus to our country's dominant civilizational program, I give the name "the imaginary Mexico"... Imaginary Mexico's westernization plan has been exclusionary and has denied the validity of Mesoamerican civilization. ${ }^{73}$

A bitter Batalla had turned Sarmiento on his head. Nevertheless, the leaders of Mexico rejected these ideas, choosing instead the free market, as the surest way out of the country's economic predicament. Mexico signed the North American Free Trade Agreement in 1992, which was revised in 2020 and renamed "the United States-MexicoCanada Agreement," and in 1994 joined the Organization for Economic Co-operation and Development. 
Another strongly worded rejection of development came in 1995, the same year that the World Trade Organization was founded, from yet another anthropologist: namely, the Columbian anthropologist Arturo Escobar, who wrote Encountering Development: The Making and Unmaking of the Third World. Escobar, whom Weinstein calls "highly provocative," condemned efforts to develop the Third World as "ethnocentric and arrogant, at best naïve." Instead of lifting up the peoples of the Third World, he alleged that Westernled efforts brought about "massive underdevelopment and impoverishment, untold exploitation and oppression." He equated "developmentalism," the mindset of the powerful over the powerless, with "orientalism" and "Africanism." Escobar cited the "debt crisis, the Sahelian famine, increasing poverty, malnutrition, and violence" as only the "most pathetic signs of the failure of forty years of development," going back to President Truman's Point Four Program. ${ }^{74}$

\section{The End of World History-and Beyond}

With the close of the Cold War, Francis Fukuyama declared in 1989 that history was at an end, not with the victory of world communism, as Marx had predicted, but with the triumph of bourgeois or neoliberal civilizations, which, in turn, were based on the universalist values and institutions of the Enlightenment": namely, free elections, free markets, and free inquiry as well as a very expensive defense. In Fukuyama's words,

What we may be witnessing is not just the end of the Cold War, or the passing of a particular period of postwar history, but the end of history as such: that is, the end point of mankind's ideological evolution and the universalization of Western liberal democracy as the final form of human government. ${ }^{75}$

He went on to clarify that "the victory of liberalism has occurred primarily in the realm of ideas or consciousness and is as yet incomplete in the real or material world." ${ }^{76}$

In this real world, the United States emerged from the Cold War as the sole superpower, as the Soviet Union, a former superpower, imploded in 1991. In the following year, Europe formed a new
United States-the European Union. At the same time, the old United States created a continentsized free trade zone with its two North American neighbors, Canada and Mexico, and issued a sweeping post-Cold War policy statement, the Defense Planning Guidance of 1992, which basically globalized the Monroe Doctrine. The U. S. declared that it would not brook the emergence of any new rival-anywhere in the world. The Monroe Doctrine of 1823, which had applied originally to the Western Hemisphere and was aimed primarily at Europe, specifically at Spain, was now extended to the entire globe and to every power and region. No power has ever before been able to so dominate its own region, in this case North America, so thoroughly and thus been free to try to extend its power elsewhere throughout the world. ${ }^{77}$

Thus, despite the passage of two centuries, world progress was still being driven by wars and markets-Adam Ferguson's clinched fist and Adam Smith's invisible hand. For the rest of the 1990s, the unipolarity of the United States provided the global security necessary for globalization, a new stage of cultural evolution or social development in which the peoples of the world were becoming increasingly interdependent, as peoples, goods, and ideas flowed freely around the Earth-less and less vexed by national borders. It was a heady time. A wealthy world finally seemed at hand. The Yugoslav Wars tested the Pax Americana as did the Global War on Terrorism but it was Vladimir Putin's annexation of the Crimean Peninsula and the breakout of the RussoUkrainian War in 2014, exactly one century after the start of the First World War, that history and geography roared back with a vengeance and the ghosts of Halford Mackinder, J. Nicholas Spykman, George Kennan, and Hans J. Morganthau were again seen haunting the world island with a renewed sense of relevance.

Indeed, as much as the United States, an established power, has tried to avoid falling into "Thucydides's Trap" with China, a rising power, it now appears to be in a cool war, as Communist China builds up its military and looks east to dominate first Hong Kong (with the new one country, one system policy) and later Taiwan as 
well as the South China Sea and as it looks west to gain influence in Eurasia and Africa by means of the Belt and Road Initiative. ${ }^{78}$ Another blow to globalization occurred in 2016 when the United Kingdom voted to leave the European Union (but not Europe) and the United States elected Donald Trump, an economic nationalist, to the presidency. Moreover, the Internet is balkanizing into a "splinternet," while Turkey, Iran, India, and Sunni Islamic radicals all vie to reclaim past imperial glories. As the Cold War came to an end, the political scientist Samuel Huntington foresaw a future "clash of civilizations" rather than an "end of history," as Fukuyama had predicted. Of the two, Huntington seems to be the one who was correct-at least in the short term. ${ }^{79}$

\section{Only Yesterday}

The Great COVID Pandemic-which began in Wuhan, China, in late 2019, after a coronavirus was transmitted from animal to a human-has accelerated de-globalization and turned public health into a security problem of the first rank. These troubling trends posed a growing threat to the American-led liberal order as well as to international economic development in general, proving that the rumors of history's demise were greatly exaggerated. Nevertheless, Fukuyama had a point. As of 2018, which seems like only yesterday, the late Swedish statistician Hans Rosling declared,

Poor developing countries no longer exist as a distinct group. That there is no gap. Today, most people, 75 percent, live in middle-income countries. Not poor, not rich, but somewhere in the middle and starting to live a reasonable life. At one end of the scale there are still countries with a majority living in extreme and unacceptable poverty; at the other is the wealthy world (of North America and Europe and a few others like Japan, South Korea, and Singapore). But the vast majority are already in the middle.

Given the data, Rosling makes the compelling case that the terms "West and the rest," "developed and developing," "rich and poor," are now passé. ${ }^{80}$
In other words, the Brandt Line had dissolved; the world frontier of social development was no longer significant. The massive economic disruption caused by COVID-19 will no doubt temporarily reverse some of this progress and levelling. Nevertheless, the universal evolutionism of the Enlightenment, which originally had existed largely as an optimistic set of ideas, was conceived at a time when there were profound disparities of social development among the world's different societies and cultures. However, by the twenty-first century, with the dramatic narrowing of these disparities or asymmetries, there was an even greater material basis for a hopeful outlook about the future of the Enlightenment project.

\section{Endnotes}

${ }^{1}$ Letter from John Adams to Abigail Adams, May 12, 1780, Adams Family Papers, An Electronic Archive, https://www.masshist.org/ digitaladams/archive/index, accessed on August 29, 2020.

${ }^{2}$ The literature on cultural evolution as well as cultural relativism is vast-two veritable oceans of immensity. Needless to say, this discussion is perforce very selective. I would like to thank my mentor Richard W. Etulain and my colleagues Deborah Cohen and Kara Moskowitz for their comments on an earlier version of this article.

${ }^{3}$ David Hume produced The History of England (1754-1761); William Robertson, The History of Scotland, 1542-1603 (1759) and The History of America (1777-1796), and Edward Gibbon, The History of the Fall and Decline of the Roman Empire (1776-1788). Of this once celebrated triumvirate, only Gibbon, sadly, continues to enjoy a wide readership.

${ }^{4}$ Francis Bacon, The New Organon, ed. by Lisa Jardine and Michael Silverthorne (1620: Cambridge, U.K.: University of Cambridge Press, 2000), 100.

${ }^{5}$ Matthew Arnold, Culture and Anarchy: An Essay in Political and Social Criticism (London: Smith, Elder, 1869), viii, Internet Archive, https://archive.org/details/dli.granth.72045/ page/n3/mode/2up, accessed August 29, 2020. 
${ }^{6}$ David Deutsch, The Beginning of Infinity:

Explanations that Transform the World (New York: Viking, 2011), 385.

${ }^{7}$ Ibid, 387 .

${ }^{8}$ See Hans Rosling, Ola Rosling, and Anna Rosling Rönnlund, Factfulness: Ten Reasons We're Wrong About the World-and Why Things Are Better Than You Think (New York, N.Y.: Flatiron Books, 2018), 27-28.

${ }^{9}$ Ibid, 23.

${ }^{10}$ Jonathan Swift, The Battle of the Books and other Short Pieces (London: Cassell and Company, 1891),13-50. The original title was "A Full and True Account of the Battle Fought Last Friday Between the Ancient and Modern Books in Saint James's Library."

${ }^{11}$ For an insightful discussion of eighteenthcentury English historiography, see Roy Porter, "The Uses of History in Georgian England" in Gibbon: Making History (New York: St. Martin's Press, 1988), 15-41.

${ }^{12}$ Duncan Forbes points out that Ferguson was born "practically on the line" between the Highlands and the Lowlands and took a "cool look at both sides of the medal of modern civilization," and what Ferguson and his fellow countrymen, including Adam Smith, "saw as the paradox of the progress of commerce and manufactures giving rise on the one hand to personal liberty and security, the blessings of the rule of law, but at the same time and equally inevitably producing a second-rate sort of society full of second-rate citizens pursuing comparatively worthless objects." See Duncan Forbes's introduction to Adam Ferguson, An Essay on the History of Civil Society (1767; Edinburgh, U.K.: Edinburgh University Press, 1966), xiii-xiv.

${ }^{13}$ Thomas Hobbes, Leviathan (1651; Oxford: At the Clarendon Press, 1909), 96-97.

${ }^{14}$ See Ian Morris, War! What is it Good For? Conflict and the Progress of Civilization from Primates to Robots (New York: Farrar, Straus and Giroux, 2014), 18.

${ }^{15}$ Ferguson, An Essay on the History of Civil Society, 232.

${ }^{16}$ Bronowski's point was that just as there was a national dimension to the contemporary American and French Revolutions, as their names make clear, so too was there a specific national character to the Industrial Revolution. This crucial change in the modes of production did indeed start in England, actually in the countryside of the Midlands, and was largely driven, at least initially, by common men. Jacob Bronowski, The Ascent of Man (Boston: Little, Brown and Company, 1973), 259.

${ }^{17}$ Adam Smith, An Inquiry Into the Nature and Causes of the Wealth of Nations, (1776; Oxford: Clarendon Press, 1976), Vol. 1., 2-3; Vol. 2., 29-30. Smith also proposed a four-stage theory of socioeconomic development. His stages were hunting, pastoralism, agriculture, and commerce. The "cake of custom" was an expression coined by the Victorian Walter Bagehot, an influential journalist, editor of The Economist, and a keen political observer. He was the author of Physics and Politics: Or, Thoughts on the Application of the Principles of "Natural Selection" and "Inheritance" to Political Society, which was published in 1872.

${ }^{18}$ Francis Parkman chose as his topic the rise and fall of New France, while for William H. Prescott it was the rise and fall of New Spain.

${ }^{19}$ Thomas Cole's The Course of Empire (18331836), a painting in five parts at the New York Historical Society, was an illustration of the rise and fall of empire. The stages were: 1 ) The Savage State; 2) The Arcadian or Pastoral State; 3) The Consummation of Empire; 4) Destruction; and finally 5) Desolation. The theme of decline was ubiquitous in Romantic art and literature. See the sonnet, "Ozymandias" (1818), by Percy Bysshe Shelley in Rosalind and Helen, A Modern Eclogue; with Other Poems (London: C. and J. Ollier, 1819), 72 , or the painting, "The Colossal Pair, Thebes" (1856), by Frank Dillon at the St. Louis Museum of Art in Missouri.

${ }^{20}$ Domingo Faustino Sarmiento, Facundo: Civilization and Barbarism, trans. by Kathleen Ross (Berkeley: University of California Press, 2003), 59. Rosas, who had already exiled Sarmiento to Chile in 1840, considered Sarmiento's book to be the best written attack on his dictatorship. See Frances G. Crowley, Domingo Faustino Sarmiento (New York: Twayne, 1972), 6.

${ }^{21}$ Frederick Jackson Turner, "The Significance of the Frontier in American History," in the 
Annual Report of the American Historical Association for 1893 (Washington, D.C.: Government Printing Office, 1894), 199-227.

${ }^{22}$ Kevin Jon Fernlund, "American Exceptionalism or Atlantic Unity? Frederick Jackson Turner and the Enduring Problem of American Historiography," in the New Mexico Historical Review 89 (Summer 2014): 359-399.

${ }^{23}$ For more on "Old Hickory in the Americas," see Lester D. Langley, America and the Americas: The United States in the Western Hemisphere (Athens: University of Georgia Press, 1989), 5455. In the United States, the franchise was extended to Black men in 1869 with the passage of the Fifteenth Amendment and to all women in 1919, with the enactment of the Nineteenth Amendment. However, the Black franchise had to be re-secured with the Voting Rights Act in 1965.

${ }^{24}$ For biographies of Sarmiento and Turner, see Frances G. Crowley, Domingo Faustino Sarmiento (New York: Twayne Publishers, 1972), Ray Allen Billington, Frederick Jackson Turner: Historian, Scholar, Teacher (New York: Oxford University Press, 1973), and Allan G. Bogue, Frederick Jackson Turner: Strange Roads Going Down (Norman: University of Oklahoma Press, 1998).

${ }^{25}$ James Ford Rhodes, "History," Annual Report of the American Historical Association, (Washington: Government Printing Office, 1899), 49-50.

${ }^{26}$ Edward B. Tylor, Primitive Culture: Researchers into the Development of Mythology, Philosophy, Religion, Art, and Custom (1871), 1.

${ }^{27}$ Lewis Henry Morgan, Ancient Society or Researchers in the Lines of Human Progress from Savagery through Barbarism to Civilization (New York: Henry Holt and Company, 1877), 19.

${ }^{28}$ Ibid., 553; Ferguson, An Essay on the History of Civil Society, 105-105.

${ }^{29}$ Morgan, Ancient Society, 553.

${ }^{30}$ See "Author's Preface to the First Edition," in Frederick Engels, The Origin of the Family, Private Property and the State, trans. by Ernest Untermann (1884; Chicago: Charles H. Kerr, 1902), 9 .

${ }^{31}$ Marvin Harris, The Rise of Anthropological
Theory: A History of Theories of Culture (1968; Walnut Creek, California: Altamira Press, 2001), 29.

${ }^{32}$ To Comte, evolution was a law for all social phenomena, past and present. "From the earliest beginnings of civilization," he wrote, "to the present state of the most advanced nations, this theory has explained consistently and dispassionately, the character of all the great phases of humanity; the participation of each in the perdurable common development, and their precise filiation; so as to introduce perfect unity and rigorous continuity into this vast spectacle which otherwise appears desultory and confused." See Auguste Comte, The Positive Philosophy of August Comte, Vol. 2, translated by Harriet Martineau (New York: D. Appleton, 1853), 465.

${ }^{33}$ In Mexico, the leading positivists were Gabino Barreda (1818-1881) and Justo Sierra (18481912).

${ }^{34}$ Like other fascists who grew up among the ruins of the Roman Empire, Carrado Gini was worried about degeneration - that "those people belonging higher up in the social ladder, those forming the upper classes, generally have a much weaker reproduction rate than the lower classes." As the Italian economist Vilfredo Pareto put it, "Whatever the underlying determinants might be, it is undisputable that after a certain period (the aristocracies) disappear. History is a cemetery of aristocracies." The Gini and Pareto quotes are from the article by Piero Manfredi and Giuseppe Annibale Micheli, "Some unnoticed Insights in Gini's Cyclical Theory of Populations" in Genus, Vol. 71, No. 2-3, Thematic issue: The Legacy of Corrado Gini in Population Studies (May-December 2015), 7-8.

${ }^{35}$ Fernlund, "American Exceptionalism or Atlantic Unity?," 362-367. At Johns Hopkins, Turner's mentor was the historian and germ theorist Herbert Baxter Adams, author of The Germanic Origin of New England Towns (Baltimore, MD.: Johns Hopkins University Studies, 1882).

${ }^{36}$ Sarmiento had also been drawn to the idea of types. To Crowley, a Sarmiento biographer, "Herein lies the key to the whole Sarmiento narrative, the very goal and dimension of his writing. People are not primarily characters in their 
own right, but rather national prototypes. These are either exemplary personages to be emulated, such as Lincoln, Franklin, and Horace Mann, or they are undesirables." Crowley, Sarmiento, 62.

${ }^{37}$ In 1946, Carlton J. H. Hayes, president of the American Historical Association and former U.S. ambassador to Spain, would challenge the ethnocentric history of his colleagues, imploring them to speak to the issues confronting Western civilization-of which the U.S. forms an integral part. See Hayes's presidential address, "The American Frontier-Frontier of What?" in the American Historical Review 50 (January 1946): 199-216.

${ }^{38}$ Franz Boas, "Human Faculty as Determined by Race," in the Proceedings of the American Association for the Advancement of Science for the Forty-Third Meeting Held at Brooklyn, New York, August 1894 (Salem: published by the Permanent Secretary, 1895), 303. Boas found himself at odds with William Henry Holmes, a cultural evolutionist who, at one point, as chief of the Bureau of American Ethnology, was one the country's foremost experts on the aboriginal peoples of the United States. In fact, in 1919 Holmes led the effort by the American Anthropological Association (AAA) to censure Boas for his public criticism of several of his fellow anthropologists. Without naming names, Boas accused them of using their positions in the field to engage in espionage for the United States during the First World War. The AAA voted to rescind the censure in 2004. See Kevin J. Fernlund, William Henry Holmes and the Rediscovery of the American West (Albuquerque: University of New Mexico Press, 2000), 225.

${ }^{39}$ Franz Boas, The Mind of Primitive Man, A Course of Lectures Delivered Before the Lowell Institute, Boston, MA, and the National University of Mexico, 1910-1911 (New York: MacMillan, 1911), 7-8.

${ }^{40}$ The influence of the Boas school extended well beyond anthropology. In his analysis of race and culture, the Harlem Renaissance intellectual Alain Locke drew upon the "extreme cultural relativism" of Robert H. Lowie, one of Bowie's students, as a point of departure. See Alain Locke, "The Concept of Race as Applied to Social
Culture," which was published in 1924 in the Howard Review and reprinted in The Philosophy of Alain Locke: Harlem Renaissance and Beyond, ed. by Leonard Harris (Philadelphia: Temple University Press, 1989), 190.

${ }^{40}$ Harris, The Rise of Anthropological Theory, 298.

${ }^{41}$ Boas's "Preface" to the 1938 edition in the rev. ed., The Mind of Primitive Man (1938; New York: The Free Press, 1963), 17-18.

${ }^{42}$ M. F. Ashley Montagu, Man's Most Dangerous Myth: The Fallacy of Race (New York: Columbia University, 1942), 47; Margaret Mead, "The Role of Small South Sea Cultures in the Post War World," American Anthropologist N. S. 45 (April-June 1943): 193-197; Ruth Benedict, The Chrysanthemum and the Sword: Patterns of Japanese Culture (Boston: Houghton Mifflin, 1946), 15; A. L. Kroeber and Clyde Kluckhohn, Culture: A Critical Review of Concepts and Definitions (Cambridge, MA: Peabody Museum of American Archaeology and Ethnology, 1952), 145.

${ }^{43}$ Harris, The Rise of Anthropological Theory, 298.

${ }^{44}$ It was ironic that Marxism's greatest appeal was in the largely agricultural and backward nations of Russia and China, which lay outside the modern and industrialized West.

${ }^{45}$ Gregor Mendel's research on garden peas, from which he derived the laws of heredity, was first published in 1866, seven years after Darwin and Wallace's co-discovery of the theory of natural selection in 1859. Not until 1900, however, was Mendel rediscovered by, as well as made famous by, three European botanists-Carl Erich Correns, Erich Tschermak von Seysenegg, and Hugo Marie de Vries-each one working independently of the other. On the fusion of Mendel and Darwin, see Julian Huxley's popular and scholarly, Evolution: The Modern Synthesis (New York: Harper and Brothers, 1942).

${ }^{46}$ Huxley, The Modern Synthesis, 578. During the Blitz, Huxley studied the effects of the bombing on animals at the London Zoo.

${ }^{47}$ Herbert Spencer, it should also be noted, had found the origins of evolution, or the increase in levels of complexity and differentiation, not in Darwin's natural selection but in the 
First Law of Thermodynamics (also called the Law of Conservation of Energy); Spencer, however, preferred "persistence" to "conservation" and "force" to "energy," hence his phrase the "Persistence of Force." This law stated that energy cannot be created or lost; it was constant, but it could also be transformed or converted into another form. Herbert Spencer, First Principles (1862; D. Appleton and Company, 1885), 190. According to Michael W. Taylor, Spencer's evolutionism had clear directionality; it was a "flow in the universe" from "simple to complex, diffuse to integrated, incoherent to coherent, independent to interdependent, undifferentiated to differentiated; from homogeneous and uniform to heterogeneous and multiform." See Taylor, The Philosophy of Herbert Spencer (London: Continuum, 2007), 63-64.

${ }^{48}$ Cultural evolution, however, was not entirely dead. Two notable cases in point were the scholarship of V. Gordon Childe, an Australian-born British archaeologist, and Karl A. Wittfogel, a German-born American Sinologist. Both scholars were Marxists and both proved to be very influential. (The Second World War turned Wittfogel into an anti-Communist.) Childe postulated a Neolithic or Agricultural Revolution, thus reconceptualizing the transition from prehistory to history. Karl A. Wittfogel's famous generalization and Marxist analysis, Oriental Despotism: A Comparative Study of Total Power (New Haven: Yale University Press), was not published until 1957. However, Wittfogel's ideas on the importance of irrigation in the rise of the bureaucratic state, advanced in a series of articles on early China dating back to 1935, influenced Julian H. Steward and other Americanists. Wittfogel's ideas appeared applicable to Andean South America and Central Mexico, where irrigation was well established, but they appeared less so in the Yucatán, with its cenotes and lagoons. On the peninsula, Mayan farmers used a slash-and-burn, or swidden, system. See Julian H. Steward, "Cultural Causality and Law: A Trial Formulation of the Development of Early Civilizations" in the American Anthropologist ${ }^{1}$ (January-March 1949): 17. Hydraulics may or may not have played a role in the rise of the Mayan civilization but it appears to have contrib- uted to their decline. See Lisa J. Lucero, "The Collapse of the Classic Maya: A Case for the Role of Water Control," in American Anthropologist 104 (September 2002): 814-826.

${ }^{49}$ Leslie A. White, "Energy and the Evolution of Culture," American Anthropologist N.S. 45 (JulySeptember 1943): 336; White, The Evolution of Culture: The Development of Civilization to the Fall of Rome (1959; Walnut Creek, CA: Left Coast Press, 2007), 38.

${ }^{50}$ White, "Energy," 336.

${ }^{51}$ Bronislaw Malinowski's field work among the Trobriand Islanders during the First World War led him to champion the study of how cultures function rather than how they develop. According to Malinowski (1884-1942), the goal of the ethnographer was to eschew ethnocentrism and to strive "to grasp the native's point of view [italics mine], his relation to life, to realise his vision of his world. We have to study man, and we must study what concerns him most intimately, that is, the hold which life has on him. In each culture, the values are slightly different; people aspire after different aims, follow different impulses, yearn after a different form of happiness. In each culture, we find different institutions in which man pursues his life-interest, different customs by which he satisfies his aspirations, different codes of law and morality which reward his virtues or punish his defections. To study the institutions, customs, and codes or to study the behavior and mentality without the subjective desire of feeling by what these people live, of realising the substance of their happiness-is, in my opinion, to miss the greatest reward which we can hope to obtain from the study of man." See Malinowski, Argonauts of the Western Pacific: An Account of Native Enterprise and Adventure in the Archipelagoes of Melanesian New Guinea (New York: E. P. Dutton, 1922), 25. Clifford Geertz's influential The Interpretation of Cultures (1973) expanded upon these ideas with an ethnography he called "thick description."

${ }^{52}$ See Leslie White's review of Julian H. Steward's Theory of Cultural Change: The Methodology of Multilinear Evolution (Urbana: University of Illinois Press, 1955) in American Anthropologist 59 (June 1957): 539-542. 
${ }^{53}$ In 1958, Gordon R. Willey and Philip Phillips outlined their own five-stage typology of historical-development for the Americas, one that has enjoyed wide acceptance. These stages were the 1) Lithic; 2) Archaic; 3) Formative; 4) Classic; and 5) Post-Classic. The two social scientists noted that "overt developmental classifications [were] comparatively new in American archaeology" and added that this was "possibly because of the strong reaction in this country," the United States, "to what [was] disdainfully referred to as 'nineteenth-century evolutionism." Gordon R. Willey and Philip Phillips, Method and Theory in American Archaeology (Chicago: University of Chicago, 1958), 64.

54 Elman R. Service, Cultural Evolutionism: Theory in Practice (New York: Holt, Rinehart and Winston, 1971), 9. An Americanist, Service postulated four stages of political evolution: 1) band, 2) tribe, 3) chiefdom, and 4) state, a scheme perhaps as influential as that of Willey and Phillips.

${ }^{55}$ Marshall Sahlins, Culture in Practice: Selected Essays (New York: Zone Books, 200o), 22-23. Although a student of White's, Sahlins's stone age affluence thesis was a provocative challenge to neo-evolutionary theory.

${ }^{56} \mathrm{C}$. P. Snow, The Two Cultures and the Scientific Revolution (New York: Cambridge University Press, 1961), 23.

${ }^{57}$ The British Houses of Parliament in London and the government edifices on Canada's Parliament Hill in Ottawa were all built in Gothic Revival, which Ruskin's criticism helped to inspire. This was considered a moral architecture, as opposed to the supposedly soul-less Neo-classical style of which the U.S. capitol and Thomas Jefferson's Monticello were good examples.

${ }^{8}$ John Ruskin, The Stones of Venice, Vol. 3, 2nd ed. (1851-1853; London: Smith, Elder, and Company, 1867), 35, 60, 95, 170. Ruskin warned his Victorian countrymen that without moral regeneration England was at risk of becoming a fallen empire like the thalassocracies of Tyre and Venice. See Ruskin, The Stones of Venice, Vol. 1, and ed. (1851-1853; London: Smith, Elder, and Company, 1858), 15.

59 Thomas Cole's five-part The Course of Empire (1833-1836), at the New York Historical Socie- ty, was an illustration of the rise and fall of empire. The stages were 1) The Savage State; 2) The Arcadian or Pastoral State; 3) The Consummation of Empire; 4) Destruction; and finally 5) Desolation. The theme of decline was ubiquitous in Romantic art and literature. See the sonnet, "Ozymandias" (1818), by Percy Bysshe Shelley in Rosalind and Helen, A Modern Eclogue; with Other Poems (London: C. and J. Ollier, 1819), 72, or the painting, "The Colossal Pair, Thebes" (1856), by Frank Dillon at the St. Louis Museum of Art.

${ }^{60}$ See "Machinery" in Mohandas K. Gandhi, Hind Swaraj or Indian Home Rule (1909), https:// www.gandhiashramsevagram.org/hind-swaraj/ chapter-19-machinery.php, accessed August 29, 2020.

${ }^{61}$ See "Education" in Mohandas K. Gandhi, Hind Swaraj or Indian Home Rule (1909), https:// www.gandhiashramsevagram.org/hind-swaraj/ chapter-18-education.php, accessed August 29, 2020.

${ }^{62}$ Snow, The Two Cultures, 26-27.

${ }_{63}$ The influence of Margaret Mead's antievolutionism on the social sciences and the humanities was legendary. However, Mead's fieldwork in, and her published conclusions on the sexual mores of, Samoa has come under withering criticism by a fellow anthropologist. See Derek Freeman, The Fateful Hoaxing of Margaret Mead: A Historical Analysis of Her Samoan Research (Boulder, CO: Westview Press, 1999).

${ }^{64}$ Carolyn Merchant, Radical Ecology (New York: Routledge, 1992), 236.

${ }^{65}$ Colin Campbell, "Anatomy of a Fierce Academic Feud," New York Times, November 9, 1986, https://www.nytimes.com/1986/11/og/education/ anatomy-of-a-fierce-academic-feud.html, accessed August 29, 2020; Michael Yudell and Rob DeSalle, "Essay Review: Sociobiology: TwentyFive Years Later," in the Journal of the History of Biology 33 (2000): 577-584, https:// link.springer.com/content/pdf/10.1023\%2FA\% 3A1004845822189.pdf, accessed August 29, 2020; John Horgan, "Stephen Jay Gould on Marx, Kuhn and Punk Meek: Paleontologist Stephen Jay Gould Was Influenced by Marx and Kuhn as well as by Darwin," in Scientific American November 2, 2015, https://blogs.scientificamerican.com/ 
cross-check/stephen-jay-gould-on-marx-kuhnand-punk-meek/, accessed August 29, 2020.

${ }^{66}$ To avoid this great power rivalry and danger, India, Egypt, Ghana, and many other underdeveloped countries formed the Non-Aligned Movement (NAM), which emerged from the 1955 Asian -African Conference, a gathering of post-colonial states, in Bandung, Indonesia. Cuba joined NAM in 1961, when the group was formed in Belgrade, and Mexico, the next-door neighbor of the United States, has observer status, enjoying, in effect, a position of non-alignment in the non-alignment movement. NAM survived the Cold War and as of 2018, has one hundred twenty members.

${ }^{67}$ To develop and not just defend South Vietnam, Johnson envisaged a New Deal for the country, specifically a billion-dollar TVA-style project for Mekong Delta. Kevin Jon Fernlund, Lyndon B. Johnson and Modern America (Norman: University of Oklahoma Press, 2009), 132-134.

${ }^{68}$ Mahbub ul Haq, Reflections on Human Development (Oxford University Press, 1996), 24, 49 $-51$.

${ }^{69} \mathrm{Ibid}$.

${ }^{70}$ Carolyn Merchant, Radical Ecology (New York: Routledge, 1992), 236.

${ }^{71}$ The "Brandt Line" was proposed in the 1980 s by Willy Brandt, the former chancellor of West Germany.

${ }^{72}$ Barbara Weinstein, "Developing Inequality," in the American Historical Review 113 (February 2008): 5-8.

${ }^{73}$ Guillermo Bonfil Batalla, México Profundo: Reclaiming a Civilization, trans. by Philip A. Dennis (1987; Austin: University of Texas Press, 1996), xv-xvi.

${ }^{74}$ Arturo Escobar, Encountering Development: The Making and Unmaking of the Third World (Princeton, N.J.: Princeton University Press, 1995), 3-4.

${ }^{75}$ Francis Fukuyama, "The End of History?" The National Interest, No. 16 (Summer 1989): 4.

${ }^{76} \mathrm{Ibid}$.

${ }^{77}$ Robert B. Zoellick, America in the World: A History of U.S. Diplomacy and Foreign Policy (New York: Twelve, 2020), 12.

${ }^{78}$ See Graham Allison, Destined for War: Can America and China Escape Thucydides's Trap?
(New York: Houghton Mifflin Harcourt, 2017). According to Allison, a "Thucydides Trap" snaps shut when an established power, like Sparta, feels threatened by a rising power, like Athens, and the former goes to war with the latter before it is too late. This concept is based on Thucydides's thesis that Sparta's fear of Athens's growing power was the cause of the Peloponnesian War. Allison found that in twelve of sixteen past cases in which a rising power has confronted a ruling power, the result was "bloodshed." As for another trap, China's "debt-trap diplomacy," Lee Jones and Shahar Hameiri call it a myth in a research paper for Chatham House. This is a practice, of which the authors say there is very little evidence, in which China is supposed to gain control over poor, developing countries by extending to them unsustainable loans for infrastructure, as part of China's strategic One Belt and Road Initiative. See "Debunking the Myth of 'Debt-trap Diplomacy': How Recipient Countries Shape China's Belt and Road Initiative," Chatham House, Research Paper, August 19, 2020, https://www.chathamhouse. org/publication/debunking-myth-debt-trapdiplomacy-jones-hameiri accessed August 24, 2020.

${ }^{79}$ Samuel P. Huntington, "The Clash of Civilizations?" in Foreign Affairs, 72, No. 3 (Summer, 1993), 22-49. In 2020, the long-standing conflict in the greater Kashmir region, which involves $\mathrm{Pa}$ kistan, India, and China, each of which represents very old civilizations, boiled over into violence in the Galwan River Valley between the military forces of India and China. That same year, on the other hand, produced the Abraham Accord, a peace agreement between Israel and the United Arab Emirates, which was brokered by the United States. The accord was called "Abraham" after the father of the Middle East's three great monotheistic religions-Christianity, Islam, and Judaism. Clearly, as these two examples indicate, civilizations may clash as well as cooperate.

${ }^{80}$ See Hans Rosling, Ola Rosling, and Anna Rosling Rönnlund, Factfulness: Ten Reasons We're Wrong About the World-and Why Things Are Better Than You Think (New York, NY: Flatiron Books, 2018), 27-28. Within the broader ascensionist narrative of modernity, there are narrower instances of failure and even of societies 
that have enjoyed booms in which they achieved a middle income status only to be reduced to poverty by painful busts, as was experienced in the Zambian Copperbelt during the 1980s, after the fall in the price of copper. See James Ferguson's Expectations of Modernity: Myths and Meaning of Urban Life on the Zambian Copperbelt (Berkeley: University of California Press, 1999). 